\title{
(RE) DEFINIÇÃO DE FRONTEIRA(S) E CIDADES GÊMEAS: BRASIL E URUGUAI
}

\section{(RE) DEFINITION OF BORDER(S) AND TWIN CITIES: BRAZIL AND URUGUAY}

\author{
${ }^{1}$ Marcia Andrea Bühring
}

\section{RESUMO}

$\mathrm{O}$ artigo tem como foco principal analisar a noção de Fronteira (s) a partir da visão tradicional de limite geográfico e político, que separa uma localidade de outra, traçando uma redefinição, mais contemporânea, levando em consideração diferentes conceitos de diferentes áreas do conhecimento. Para tanto, a identificação das cidades gêmeas, e mais especificamente uma das fronteiras (Brasil e Uruguai), com verificação pontual das cidades gêmeas, cujo limite se dá por meio de uma avenida: Santana do Livramento(BR)/Rivera(UR) e Chuí(BR)/Chuy(UR), que ao mesmo tempo em que separa, une os dois países. Dentre os muitos acordos e ajustes para concretizar direitos sociais, a partir do Estatuto Jurídico da Fronteira entre Brasil e Uruguai firmado em 20 de dezembro de 1933, e do Ajuste Complementar ao Estatuto, de 06 de maio de 1997, bem como o Acordo para Permissão de Residência, Estudo e Trabalho a Nacionais Fronteiriços Brasileiros e Uruguaios, de 21 de agosto de 2002; Também o Ajuste Complementar ao Acordo para Prestação de Serviços de Saúde, em 2008, Decreto $n^{\circ} 7.239 / 10$, que possibilita o trânsito e utilização dos serviços de saúde de ambos os lados. E mais recentemente, o Decreto n. ${ }^{\circ} 8.455$, de 20 de maio de 2015, que promulga o Acordo entre os dois governos para a Criação de Escolas e/ou Institutos Binacionais Fronteiriços Profissionais e/ou Técnicos e para o Credenciamento de Cursos Técnicos Binacionais Fronteiriços. Quanto a metodologia utilizada, adotou-se o método dedutivo. Conclui-se portanto, que a Fronteira (s) é um não lugar, um lugar incomum, um vazio fronteiriço, que separa e que une ao mesmo tempo, e cuja verificação da concretização dos direitos sociais tem-se dado por meio do Acordo e dos Ajustes Internacionais.

Palavras-chave: Fronteira, Não lugar, Acordo e ajustes internacionais

\begin{abstract}
The article focuses primarily on analyzing the notion of Border (s) from the traditional view of geographical and political boundary that separates one location to another, tracing a redefinition, more contemporary, taking into account different concepts from different areas of knowledge. Therefore, the identification of the Twin Cities, and more specifically one of the borders (Brazil and Uruguay), with spot-checking of the Twin Cities, whose limit is through an avenue: Santana do Livramento (BR) / Rivera (RH) and Chui (BR) / Chuy (UR), which while separating, unites the two countries. Among the many agreements and adjustments to realize social rights from the Border Legal Status between Brazil and Uruguay signed on December 20, 1933, and the Supplementary Agreement to the Status of May 6,
\end{abstract}

\footnotetext{
${ }^{1}$ Doutora em Direito pela Pontifícia Universidade Católica do Rio Grande do Sul - PUCRS, Rio do Grande Sul, RS, (Brasil). Professora na Pontifícia Universidade Católica do Rio Grande do Sul, PUCRS, Rio Grande do Sul.(Brasil) .E-mail.: marcia.buhring@pucrs.br.
} 
1997, and the Agreement to Permit residence, study and work the National Border Brazilians and Uruguayans, of August 21, 2002; Also the Supplementary Agreement to the Agreement for Health Service Delivery in 2008, Decree No. 7,239 / 10, which allows the transit and use of health services from both sides. And more recently, the Decree No. 8455, of May 20, 2015, which promulgates the Agreement between the two governments for Schools Creation and / or Institutes Binational Border professionals and / or technicians and the Binational Technical Courses Accreditation border. As for methodology, it adopted the deductive method. We conclude therefore that the Border (s) is not a place, an unusual place, a border empty, separating and uniting at the same time, and whose verification of the achievement of social rights has been given by the Agreement and the International settings.

Keywords: Border, No place, Agreement and international settings

\section{INTRODUÇÃO}

Historicamente a fronteira possui um conceito tradicional, ligado a questões de diplomacia, guerras e a política. Contemporaneamente, é vista como inclusão, como tentativa de efetivação de direitos sociais, visto que se trata de um lugar atípico, diferente, que limita, mas que também inclui.

O Problema de pesquisa, é justamente redefinir essa fronteira, verificando como a temática é discutida em diferentes áreas do conhecimento, a fim de traçar um contorno atual para ela, e que represente em termos práticos o que se está fazendo para concretização de direitos resultantes dessa interação.

O objetivo principal é mostrar que existem em termos práticos, dentre muitos acordos e ajustes, a partir do Estatuto Jurídico da Fronteira entre Brasil e Uruguai firmado em 1933, e do Ajuste Complementar ao Estatuto, em 1997, especificamente o Acordo para Permissão de Residência, Estudo e Trabalho a Nacionais Fronteiriços Brasileiros e Uruguaios, de 2002, ou seja, os fronteiriços, ou doble-chapas, como são chamados, possuem o livre arbítio, para morar, estudar, trabalhar, onde escolherem, claro: desde que incluídos nas localidades especificadas, as chamadas cidades gêmeas.

Por outro lado também o Ajuste Complementar ao Acordo de 2008, possibilita o trânsito e uso dos serviços de saúde (SUS-SNIS) de ambos os lados.

E mais recentemente, o Acordo entre os dois países para a Criação de Escolas e/ou Institutos Binacionais Fronteiriços Profissionais e/ou Técnicos e para o Credenciamento de Cursos Técnicos Binacionais Fronteiriços, o que representou um grande avanço.

Justifica-se a escolha da temática, em razão dessa atipicidade, seja em razão do lugar, seja em razão do convívio, seja em razão da identidade, dos laços familiares que 
são formados, etc., sendo que um recorte se fez necessário até porque são hoje 29 pares de cidades gêmeas no Brasil. Então, a opção por duas localidades, cuja separação física se dá por meio de uma rua-avenida, ou melhor, uma fronteira seca, tanto em Santana do Livramento(BR)/Rivera(UR) quanto no Chuí(BR)/Chuy(UR).

Como método de pesquisa, utilizar-se-á o dedutivo, pois parte-se da análise do geral para o particular, com a revisão bibliográfica, e legislativa sobre a temática em comento.

A estrutura, segue num primeiro item a análise da noção de fronteira em diferentes areas do conhecimento, passando pela história, leteratura, sociologia, geografia, etc. Para, num momento posterior verificar o que se entende por área, zona e faixa de fronteira, comanálise do que se entende por cidades gêmeas. Para ao final apresentar além da redefinição de fronteira, aqueles Acordos e ajustes, que dizem respeito a efetivação de direitos sociais.

\section{NOÇÃO DE FRONTEIRA: EM DIFERENTES ÁREAS DO CONHECIMENTO}

O termo fronteira surge em diferentes contextos, momentos, áreas do conhecimento/disciplinas. Contudo, um acordo semântico se faz necessário, em razão do próprio objeto do artigo: fronteira aqui será utilizada como um lugar incomum, um "não lugar", um vazio fronteiriço.

A palavra fronteira abre um leque de possibilidades, optou-se por fazer uma abordagem, apontando o significado do termo fronteira(as) em diferentes áreas do conhecimento, (do tradicional ao novo) a exemplo da história, literatura, antropologia, sociologia, geografia, filosofia, e que podem ser utilizados como elo com o direito.

O radical da palavra fronteira deriva do latim frons ou frontis, - fronte, cabeça, testa, frontaria, indicava o terreno que se situava "in fronte", ou seja, na frente, nas margens, explica Lia Osório Machado (1998, p. 41):

\footnotetext{
A palavra fronteira implica, historicamente, aquilo que sua etimologia sugere - o que está na frente. A origem histórica da palavra mostra que seu uso não estava associado a nenhum conceito legal e que não é um conceito essencialmente político ou intelectual. Nasceu como um fenômeno da vida social espontânea, indicando a margem do mundo habitado.
}

Por importante a definição do Dicionário Aurélio: "Fron.tei.ra s.f. (fronte + eira) 
1 Zona de um país que confina com outra do país vizinho. 2 Limite ou linha divisória entre dois países, dois Estados, etc. 3 Raia; linde. 4 Marco, baliza. 5 Confins, extremos".(FERREIRA, 1986, p. 814).

A visão tradicional da fronteira, que diz respeito ao campo da história (diplomática e militar), está vinculada diretamente ao âmbito político - estatal, como fruto de tratados e negociações diplomáticas, ou vitórias heróicas, e que tem um significado especial de acordo com a sociedade que se forma. (OSÓRIO, 1995, p. 110).

Uma dinâmica fronteiriça, uma realidade que se move, com ambíguos significados, sem esquecer o sentido tradicional empregado, ${ }^{1}$ todavia novos enfoques surgem, a história está ligada a cultura, e no contexto das fronteiras as pessoas comuns que ali habitam aquele lugar-espaço, são portanto agentes históricos, (CAMPIGOTTO, 2006, p. 23) pois nesse espaço fronteiriço, esses agentes não são neutros, tanto que são eles que dinamizam a fronteira, (BALLER, 2008, p. 86) ou seja, à fronteira, como espaço efetivamente ágil e dinâmico de interelações.

Para o campo da literatura, a fronteira divide o espaço do texto em subespaços impenetráveis, ${ }^{2}$ também uma forma de definir fronteira. E aqui, vale ainda a ressalva tangenciada por Michel de Certeau, trazendo esse limite e a transgressão desse limite, no cotidiano, como "um vácuo, símbolo narrativo de intercâmbios e encontros". ${ }^{3}$ É um "não lugar", ou seja, um limite "entre dois", um terceiro lugar. A titulo de exemplo ainda, na literatura, a analogia, do transito de um não-lugar a outro, (BORGES FILHO, 2008, p. 13), como na mitologia grega - dois mundos, ou melhor, entre mundos, mas que nunca chega ao lugar desejado.

As fronteiras "apresentam-se no imaginário social como um limite" ou seja são “elementos simbólicos carregados de ambiguidades, pois, ao mesmo tempo em que impedem, permitem ultrapassar", (MELO, 1997, p. 68-69) é também fato social, e que vai muito além do aspecto geográfico, necessário se torna, "retomar a expressão "regere

\footnotetext{
${ }^{1}$ Refere: "o relato diplomático valoriza a história dos grandes personagens, que batalharam pela conquista e defesa do território ao qual pertencem, enfatizando, além dos interesses em jogo das nações envolvidas, o patriotismo, a coragem e a honra. Estas disputas não competem apenas à luta em campo aberto, mas, sobretudo e também, desde os gabinetes dos palácios governamentais. Os novos enfoques sociológicos, antropológicos e historiográficos têm propiciado uma abertura de estudos referente ao tema. Esses estudos focam as relações sociais e as práticas culturais e, por que não dizer, a cultura específica dessas populações no ambiente de fronteira. O aprofundamento do sentido mais amplo da definição de fronteira se faz necessário para o entendimento dela pela população, bem como para os teóricos que refletem sobre a temática. (BALLER, 2008. p.86-87).

${ }^{2}$ Como informa Ozíris Borges Filho: O único teórico a tratar desse interessante tema na obra literária foi o russo
} 
fines" que significa traçar em linha reta as fronteiras, os limites. É o mesmo procedimento utilizado pelo padre na construção de um templo ou de uma cidade, quando ele determina esse espaço consagrado sobre o terreno", é delimitar (interior e exterior).(RAFFESTIN, 2005, p. 10).

Além do fato social, pode-se mencionar o espaço social, o diálogo que pode ser realizado entre a sociologia e as ciências jurídicas e sociais é profícuo, como a própria noção de habitus, (ou habito social) $2^{\circ}$ obras de Norbert Elias e Pierre Bourdieu que é fundamental, como aduz Norbert Elias o espaço social é chamado de outsiders. ${ }^{4} \mathrm{O}$ problema menciona o autor, é saber - como e por que - os “indivíduos percebem uns aos outros como pertencentes a um grupo e se incluem mutuamente dentro das fronteiras grupais que estabelecem ao dizer 'nós'," sendo que "excluem outros seres humanos a quem percebem como pertencentes a outro grupo e a quem referem coletivamente como 'eles"”. (ELIAS, 2000, p. 36-68).

Essa relação (do conceito de habitus) entre os dois autores também é explicitado por Jurandir Malerba, por um lado, "Elias concebe a possibilidade de transformações do habitus decorrentes de mudanças históricas, as quais incidem sobre a hierarquia das posições", por outro lado, Bourdieu concebe o habitus "como os limites de ação, das

\footnotetext{
Iuri Lotman “... um traço topológico muito importante é a fronteira. A fronteira divide todo o espaço do texto em dois subespaços, que não se tornam a dividir mutuamente. A sua propriedade fundamental é a impenetrabilidade. O modo como o texto é dividido pela sua fronteira constitui uma das suas características essenciais. Isso pode ser uma divisão em «seus» e alheios, vivos e mortos, pobres e ricos. O importante está noutro aspecto: a fronteira que divide um espaço em duas partes deve ser impenetrável e a estrutura interna de cada subespaço, diferente. Pelo trecho acima percebemos já algumas características muito importantes para a topoanálise da fronteira. Primeira característica é a divisão de todo o texto em dois espaços que não se tornam a dividir. Em outras palavras, a fronteira não divide apenas um ponto particular do espaço no texto literário, mas é um corte grandioso, longitudinal. Dessa maneira, não podemos considerar fronteira um muro que separa a casa de uma personagem e outra a não ser que todo o espaço da trama seja as duas casas. Se houver outros espaços como teatros, cafés, cinemas, etc. nesse texto e pelos quais as personagens transitam livremente, não teremos uma fronteira. Outra característica importante sobre a fronteira que podemos perceber no trecho citado de Lotman é a idéia de impenetrabilidade." (BORGES FILHO, 2008).

3 "Transgressão do limite, desobediência à lei do lugar, ela representa a partida, a lesão de um estado, a ambição de um poder conquistador, ou a fuga de um exílio, de qualquer maneira a "traição" de uma ordem. Mas ao mesmo tempo ergue um alhures que extravia, deixa ou faz ressurgir, fora das fronteiras, a estranheza que era controlada no interior, dá objetividade (ou seja, expressão e representação) à alteridade que se escondia do lado de cá dos limites, de sorte que cruzando a ponte para lá e para cá e voltando ao recinto fechado, o viajante aí encontra agora o outro lugar que tinha a princípio procurado partindo e fugido depois voltando. No interior das fronteiras já está o estrangeiro, exotismo o sabbat da memória, inquietante familiaridade. Tudo ocorre como se a própria delimitação fosse a ponte que abre o dentro para seu outro. Então, pergunta-se: a quem pertence a fronteira? Nem a um, nem a outro. (fronteira funciona como um terceiro, é um "entre dois"). Lugar terceiro, jogo de interações e de entrevistas, a fronteira é como um vácuo, símbolo narrativo de intercâmbios e encontros". (CERTEAU, 2003. p.213-215).
} 
soluções ao alcance do indivíduo em uma determinada situação social concreta”, (MALERBA, 2000, p. 15-18) é produto da história traduzido nas práticas (individuais e coletivas).

Note-se que fronteira é o que Pierre Bordieu definiu de região, relacionado à luta simbólica de "fazer crer e fazer ver, de dar a conhecer e fazer reconhecer, de impor as definições legítimas das divisões do mundo social e, por este meio, de fazer e desfazer os grupos". 5

Seguindo a linha das novas realidades socioculturais, a fronteira corresponde a espaços de dualidades, é ao mesmo tempo área de separação e aproximação, (CASTELLO, 1995, p. 18) ou melhor, linha de barreira e espaço polarizador, ainda, fenômenos duais, como referido por Eric Hobsbawn, (1994, p. 19-20)“construídos essencialmente pelo alto, mas que, no entanto, não podem ser compreendidas sem ser analisadas de baixo", isso consiste "em termos das suposições, esperanças, necessidades, aspirações e interesses das pessoas comuns, as quais não são necessariamente nacionais e menos ainda nacionalistas", (1994, p. 19-20) pertencer ao lugar, integrar-se e sentir-se parte do conjunto.

E, nesse sentido, Manuel Castels, (2006. p. 453) traz o significado social do espaço e do tempo, enquanto dimensões da vida humana, ${ }^{6}$ ao que adverte Miguel Reale, (1992, p. 218) que é "inconcebível uma estrutura social que seja desvinculada do processo histórico", essa é a própria função do direito. ${ }^{7}$

\footnotetext{
${ }^{4}$ Os termos estabelecidos e outsiders correspondem ao título da obra de Norbert Elias e John L. Scotson. Os estabelecidos de maneira geral correspondem a um grupo social que habita um espaço há vários anos, apresentando-se como residentes a mais tempo naquele espaço social. Os outsiders de maneira geral são as pessoas que vêm de fora e passam a viver no mesmo espaço social. Essa classificação é genérica e não representa uma diferenciação entre os grupos, seja em relação à etnia, classe social, cargos empregatícios, entre outras possíveis diferenças. (BALLER, 2008. p.114).

${ }_{5}^{5}$ Por outro lado, Pierre Bourdieu, aponta que o mundo social é o espaço. "Os agentes e grupos de agentes são assim definidos pelas suas posições relativas neste espaço. Cada um deles está acantonado numa posição ou numa classe precisa de posições vizinhas, quer dizer, numa região determinada do espaço [...]. Na medida em que as propriedades tidas em consideração para se construir este espaço são propriedades atuantes, ele pode ser descrito também como campo de forças, quer dizer, como um conjunto de relações de forças objetivas impostas a todos os que entrem nesse campo e irredutíveis às intenções dos agentes individuais ou mesmo às interações diretas entre os agentes". (BOURDIEU, 2005. p.134).
} 
O espaço de fluxos, (de capital, trabalho, informação, etc...) o espaço de expressão da sociedade, ${ }^{8}$ reafirme-se, com novas formas e processos espaciais, o espaço não é reflexo é expressão da sociedade, é a própria sociedade, e o "tempo intemporal pertence ao espaço de fluxos, enquanto a disciplina temporal, a seqüencia biológica, determinada pela sociedade caracteriza lugares ao redor do mundo". 9

Ainda que referindo a sociedade em rede, cujo lugar é uma localidade cuja forma, função e significado estão delimitados pelas fronteiras de contiguidade física, ${ }^{10}$ também chamados de hiperespaço social, ${ }^{11}$ e que atualmente, no mundo de fluxos globais de riqueza, poder e imagens na busca da identidade, seja coletiva, ou individual, atribuída ou construída, que se converte na fonte fundamental do significado social, ${ }^{12}$ conclui Manuel Castels:

E, menciona essa relação de poder Claude Raffestin, (1993, p. 165) fica clara e evidente na fronteira que é "compreendida como zona de contacto e limite, ou seja, é uma linha de separação definida que cristalizada se torna então ideológica, pois justifica territorialmente as relações de poder”, embora Michael Foucault, (1985, p. 14)adverte que o poder não existe, o que existe são "práticas ou relações de poder", e esse espaço

\footnotetext{
6 "Espacio y tempo son las dimensiones materiales fundamentales de la vida humana. [...]. proponho la hipótesis de que el espacio organiza al tempo em la sociedade red.[...]". (CASTELLS, 2006. p.453).

${ }^{7}$ Argumenta: "Quando, porém, se fala na 'estrutura tridimensional do direito', neste conceito já está implícita a nota essencial da temporalidade, pois é inconcebível uma estrutura social estática, desvinculada do processo histórico: o direito, como a realidade social toda da qual participa, é, fundamentalmente, uma estrutura tridimensional e histórica, distinguindo-se das demais por possuir uma nota específica, que é a bilateralidade atributiva inerente a todas as formas de ordenação jurídica da conduta humana. Essas três características essenciais de tridimensionalidade, temporalidade e bilateralidade-atributiva, penso estarem sintetizadas quando conceituo o Direito como realidade histórica-cultural tridimensional de natureza bilateral atributiva". (REALE, 1992. p.218).

8 Tradução livre de: "El espacio es la exression de la sociedade. Puesto que nuestras sociedades están sufriendo una transformación estructural, es uma hipótesis razonable sugerir que están surgiendo nuevas formas y procesos espaciales.[...] el espacio no es un reflejo de la sociedade, sino su expresión. En otras palabras, el espacio no e uma fotocopia de la sociedade: es la sociedad misma. [...] nuestra sociedade está construida en torno a flujos: (flujos de capital, información, tecnología, interacción organizativa, imágenes, sonidos y símbolos). Los flujos no son sólo un elemento de la organización social: son la expresión de los procesos que dominan nuestra vida económica, política, y simbólica.[...] El espacio de los flujos es la organización material de las prácticas sociales en tempo compartido que funcionan a través de los flujos. Pues flujos entiendo las secuencias de intercambio e interacción determinadas, repetitivas y programables entre las posiciones físicamente inconexas que mantienen los actores sociales en las estructuras sociales dominantes. Por estructuras dominantes entiendo los dispositivos de organizaciones e instituciones cuya lógica interna desempeña un papel estratégico para dar forma a las prácticas sociales y la consciencia social de la sociedad en general”. (CASTELLS, 2006. p.488-490).

9 Tradução livre de: "El tempo atemporal pertenece al espacio de los flujos, mientras que la disciplina temporal, el tempo biológico y la secuenciación determinada por la sociedade caracterizan a los lugares de todo el mundo, estructurando y desestructurando materialmente nuestras sociedades segmentadas". (CASTELLS, 2006. p.545).
} 
social pode ser um espaço multidimensional, ${ }^{14}$ e essas relações sociais-político-culturais estão impregnadas do simbólico, nas palavras de Pierre Bourdieu, (2005, p. 11) produções simbólicas, privilegiando seus interesses. ${ }^{15}$

Portanto a fronteira é produção simbólica "que responde ou corresponde aos interesses, às condições, as circunstâncias, aos valores e visões de mundo das pessoas envolvidas no processo histórico concreto de sua constituição”. (BALLER, 2008, p. 103).

Espaço que também é definido por Milton Santos, (1996, p. 15) como "lugar banal: locus da solidariedade coletiva, da contigüidade, da vizinhança e do território compartido", também o limite, que se transforma em fronteira, ou seja, "foi concebido para delimitar territórios com precisão como se fosse uma linha divisória, espraia-se em uma zona de interface e de transição entre dois mundos tomados distintos". ${ }^{16}$

Esses dois mundos, um deles, simplesmente reproduzido, artificial e o outro real, efetivo, "fora do mapa, a vida pulsa, põe o mundo em movimento e amplia as fronteiras entre as duas peças”. (HISSA, 2006, p. 28).

Assim as fronteiras são "o produto da capacidade imaginária de reconfigurar a realidade", se há dificuldade em pensá-las, em apreendê-las, "é porque aparecem tanto reais como imaginárias, intransponíveis e escamoteáveis", são dois mundos distintos e complexos. (HANCIAU, 2005, p. 133).

\footnotetext{
${ }^{10}$ Tradução Livre de: "El espacio de los flujos no impregna todo el ámbito de la experiencia humana en la sociedade red. En efecto, la inmensa mayoría de la gente, tanto en las sociedades avanzadas como en las tradicionales, vive en lugares y, por lo tanto, percebe su espacio en virtud de ellos. Un lugar es uma localidades cuya forma, función y significado están delimitados por las fronteras de la contigüidad física". (CASTELLS, 2006. p.501-502).

${ }^{11}$ Tradução livre de: "em dimensiones diferentes de um hiperespacio social". (CASTELLS, 2006. p.506).

${ }^{12}$ Prólogo: Tradução livre de: "Los cambios sociales son tan espectaculares como los procesos de transformación tecnológicos y económicos. [...] En un mundo de flujos globales de riqueza, poder e imágenes, la búsqueda de la identidad, colectiva o individual, atribuida o construida, se convierte en la fuente fundamental de significado social". (CASTELLS, 2006. p.32).

${ }^{13}$ Tradução livre de: Nuestra exploración de las estructuras sociales emergentes por distintos ámbitos de la actividad y experiencia humanas conduce a uma conclusión general: como tendencia histórica, las funciones y los procesos dominantes en la era de la información cada vez se organizan más en torno a redes. Éstas constituyen la nueva morfología social de nuestras sociedades u la difusión de su lógica de enlace modifica de forma substancial la operación y los resultados de los procesos de producción, la experiencia, el poder y la cultura". (CASTELLS, 2006. p.549-550).

14 “[...] na realidade, o espaço social é um espaço multidimensional, conjunto aberto de campos relativamente autônomos, quer dizer, subordinados quanto ao seu funcionamento e às suas transformações, de modo mais ou menos firme e direto ao campo de produção econômica: no interior de cada um dos subespaços, os ocupantes das posições dominantes e os ocupantes das posições dominadas estão ininterruptamente envolvidos em lutas de diferentes formas (sem por isso se constituírem necessariamente em grupos antagonistas).”. (BOURDIEU, 2005. p.153).
} 
Observe-se ainda, por importante, que a região é o espaço fronteiriço, na percepção tradicional a fronteira é o limite, o corte, a descontinuidade, a barreira entre Estados Nacionais. No tocante a geopolítica é um “órgão periférico do Estado que tanto pode ser receptora de influências como pode ser pólo de irradiação, projetando-se sobre os países vizinhos”, (PADRÓS, 1997, p. 72) e no tocante a perspectiva integracionista, a integração fronteiriça "sintetiza a sobreposição de fluxo e forças de atração de diversa intensidade que origina um novo espaço conjunto onde anteriormente existiam dois espaços separados e impermeáveis entre si”. (PADRÓS, 1997, p. 72).

Tanto que, fronteira é territorialidade permeável à mobilidade social, vez que, se estabelecem múltiplas relações sociais, culturais, econômicas e comerciais se estabelecem, fronteira não é limite à cidadania, é antes processo de interação. (BUTIERRES, 2008).

Nesse contexto ainda, Peter Burke (2005 p. 10) nos seus estudos culturais no final do século XX, inicio do século XXI frisa:

o terreno comum dos historiadores culturais pode ser descrito como a preocupação com o simbólico e suas interpretações. Símbolos, conscientes ou não, podem ser encontrados em todos os lugares, da arte à vida cotidiana, mas a abordagem do passado em termos de simbolismo é apenas uma entre outras. ${ }^{17}$

Ainda no campo da história, José Adilçon Campigoto (2006, p. 17-18) traz a problemática da fronteira vinculada ao local fronteiriço e aos sentimentos de pertencimento, esse lugar periférico, “em que vivem e pelo qual transitam sujeitos excluídos da sociedade brasileira e paraguaia, os sentidos de fronteira constituem um terceiro lugar, nem Brasil, nem Paraguai". É a história desenvolvida "para além do circuito fechado pela sociedade, porque é protagonizada pelos excluídos, por sujeitos que não se definem como brasileiros nem como paraguaios". (CAMPIGOTTO, 2006, p. 17 18).

\footnotetext{
${ }^{15}$ Comenta: "As diferentes classes e frações de classes estão envolvidas numa luta propriamente simbólica para imporem a definição do mundo social mais conforme aos seus interesses, e imporem o campo das tomadas de posições sociais ideológicas reproduzindo em forma transfigurada o campo das posições sociais”. (BOURDIEU, 2005. p.11).

16 Refere: "Fronteiras e limites, em princípio, fornecem imagens conceituais equivalentes. Entretanto, aproximações e distanciamentos podem ser concebidos entre fronteiras e limites. Focaliza-se o limite: ele parece consistir de uma linha abstrata fina o suficiente para ser incorporada pela fronteira. $\mathrm{O}$ marco de fronteira, reivindicando o caráter de símbolo visual do limite, define por onde passa a linha imaginária que divide territórios. A fronteira coloca-se à frente, como se ousasse representar o começo de tudo onde exatamente parece terminar: o limite, de outra parte, parece significar o fim do que estabelece a coesão do território. O limite estimula a ideia sobre a distância e a separação, enquanto a fronteira movimenta a reflexão sobre o contato e a integração. Entretanto, a linha que separa os conceitos é espaço vago e abstrato". (HISSA, 2006. p.34).
} 
É o que Stuart Hall (2003, p. 84-85) refere enquanto sociedade multicultural, que "sempre envolve mais do que um único grupo", e justamente por novas áreas ganharem destaque, no campo da sociologia, o termo fronteira, passa a ter uma abrangência maior, com uma ampla gama de significados, quais sejam, culturais, políticos e econômicos, é fronteira de diferentes coisas "fronteira da civilização, fronteira espacial, fronteira de culturas e visões de mundo, fronteira de etnias, fronteira da história e da historicidade do homem. E, sobretudo, fronteira do humano". (MARTINS, 1997, p. 13).

Há uma forte ligação entre identidade, fronteira e cultura, (BALLER, 2008, p. 86) por isso adverte a fragilidade das culturas locais deve ser observada, ${ }^{18}$ num contex to sócio cultural de fronteira, onde "cotidianamente se entrecruzam diferentes etnias, em razão da intensa circulação de pessoas, a etnicidade desenvolve-se de forma inevitável”.(PEREIRA, 2003, p. 140).

Ou seja, é no conceito de não lugar de Marc Auge, também chamado de lugar incomum ou de espaços de anonimato, que os fenômenos locais ganham significado.E é justamente essa referência coletiva, esse lugar que une e que separa que existe na fronteira, nas cidades gêmeas, especificamente Brasil e Uruguai.

Ademais, o lugar-comum, adverte Marc Auge, (2000, p. 49) ${ }^{19}$ é o lugar, onde os nativos vivem, trabalham, cuidam das fronteiras, lugar de culto dedicado aos ancestrais. Esse lugar comum é uma invenção sendo que um bom exemplo disso são as migrações do campo para a cidade e a formação de novos povoados, ou seja, a natureza dos grupos são sempre diversa, mas a identidade do lugar se une, funde-se, converge-se em um lugar próprio daqueles que passam a ocupar o lugar. ${ }^{20}$ (AUGE, 2000, p. 51). E aqui é perfeitamente possível trazer a fronteira enquanto não lugar.

\footnotetext{
${ }^{17}$ OBS: Quando esteve no Brasil em 2007, nas Fronteiras do Pensamento, comentou sobre a globalização da cultura, ou se o mundo todo fosse Brasil - 10/04/2007 dando relevância aos aspectos socioculturais em suas análises. "Em sua conferência, Peter Burke discorreu sobre globalização e identidade global. Frente aos avanços da tecnologia, sustentou que as instituições, apesar de se atrasarem, também se adaptam às rápidas transformações. Porém, a principal barreira é a mentalidade e o comportamento, mais rígidos e lentos para aceitarem as mudanças. Positivo quanto ao novo homem global, Burke defendeu como o desequilíbrio ecológico tem acelerado o processo da identidade única, sendo esta essencial para o futuro do planeta." (Acesso em: 01 fev. 2013).

${ }^{18}$ Aduz: "A história tradicional, como querem algumas perspectivas políticas, acaba por diminuir o sentido das fronteiras. As teorias geopolíticas também compactuam com essas opções manipuladoras, percebendo em cada
} 
Utiliza Marc Auge, (2000, p. 55) ainda, o conceito de ilha para referir que ali estão claramente definidos os contornos da fronteira, ${ }^{21}$ enquanto lugar de excelência da totalidade pelos claros contornos entre a zona de identidade relativa, ou seja, reconhecida e de relações instituídas, e o mundo exterior, ou seja, da estranheza absoluta ou (do estrangeiro) absoluto. (AUGE, 2000, p. 55-56).

Portanto, lugar é, segundo o autor, o espaço antropológico, a identidade, a relação e a história, e o não lugar é o contrário: o não relacional, não identitário e não histórico. Como exemplo de não lugar, os povoados de "viajantes" ou "passeantes", ou ainda “transeuntes". Esses viajam sozinhos, nos espaços de ninguém. Tem revelado uma nova forma de "viver" o mundo. Muito embora o retorno ao lugar pode ser o sonho dos que frequentam os não lugares. São, por conseguinte os não lugares livres de identidades. (AUGE, 2000, p. 56). É estar sozinho, sem saber que está sozinho, é sentir-se parte integrante do contexto produzido pela sociedade, ou esperado pela sociedade, se está em contato com outras pessoas, sem efetivamente ou de fato estar com alguém.

O não lugar, ou o espaço vazio, (BAUMANN, 2001, p. 115-116) caracteriza-se pela ausência dos símbolos (identidade, relação e história), (AUGE, 1994, p. 156) pois é a negação do lugar, nessa linha de raciocínio, adverte ainda, Marc Augé, o estrangeiro não se reconhece no outro, quando todo o espaço "se assemelha somos de certo modo

ponto um problema de hegemonia, especialmente relativo ao espaço e ao tempo que geram um país ou nação, o que busca evidenciar a fragilidade das culturas locais em detrimento desse complexo espaço fronteiriço. Estas concepções tradicionais de fronteira muitas vezes acabam por influenciar e direcionar até mesmo os cientistas sociais". (BALLER, 2008. p.86).

${ }^{19}$ Tradução livre de: "El lugar común al etnólogo y a aquellos de los que habla es un lugar, precisamente: el que ocupan los nativos que en él viven, trabajan, lo defienden, marcan sus puntos fuertes, cuidan las fronteras pero señalan también la huella de las potencias infernales o celestes, la de los antepasados o de los espíritus que pueblan y animan la geografía íntima, como si el pequeño trozo de humanidad que les dirige en ese lugar ofrendas y sacrificios fuera también la quintaesencia de la humanidad, como si no hubiera humanidad digna de ese nombre más que en el lugar mismo del culto que se les consagra". (AUGE, 2000. p.49).

${ }^{20}$ Tradução livre de: "Que los términos de este discurso sean voluntariamente espaciales no podría sorprender, a partir del momento en que el dispositivo espacial es a la vez lo que expresa la identidad del grupo (los orígenes del grupo son a menudo diversos, pero es la identidad del lugar la que lo funda, lo reúne y lo une) y es lo que el grupo debe defender contra las amenazas externas e internas para que el lenguaje de la identidad conserve su sentido". (AUGE, 2000. p.51).

${ }^{21}$ Tradução livre de: "[...] pero también es significativo que uma isla (una islita) sea propuesta ejemplarmente como el lugar por excelencia de la totalidad cultural. De una isla, se pueden delinear o dibujar sin vacilación los contornos y las fronteras; de isla en isla, en el interior de un archipiélago, los circuitos de la navegación y del intercambio componen itinerarios fijos y reconocidos que delinean una clara frontera entre la zona de identidad relativa (de identidad reconocida y de relaciones instituidas) y el mundo exterior, el mundo de la extranjeridad absoluta". (AUGE, 2000. p.55-56). 
todos estrangeiros porque já nada nos identifica", (AUGE, 1994, p. 156) essa falta de nexo entre a pessoa e o lugar, é muito comum na região de fronteira. A noção de lugar e não lugar são noções que possuem um limite, "que correspondem a espaços muito concretos, mas também a atitudes, a posturas, à relação que os indivíduos mantêm com os espaços onde vivem ou que eles percorrem" (AUGE, 1994, p. 167).

Traz ainda, o lugar objetivo, o lugar da identidade e o lugar simbólico o espaço onde se estabelecem as relações, (AUGE, 1994, p. 141) assim como os não lugares objetivos os espaços de circulação-comunicação-consumo. E os não lugares subjetivos os espaços pelos modos de relação com o exterior, um constante ir e vir do espaço construído ao vivido. O que Marc Augé faz é relacionar os não lugares com diferentes fenômenos seja “do espaço construído e a relação dos indivíduos com ele”. (AUGE, 1994, p. 141).

Contemporaneamente, vive-se em tempos líquidos, (expressão cunhada por Zigmunt Baumann, (2001) nada é feito para durar, a mudança é instantânea, e refere à comunidade definida por suas fronteiras vigiadas pelos estranhos que se encontram ou (desencontram). (BAUMANN, 2001, p. 111-112)22 Além dos espaços públicos, que servem de ponto de encontro (entre estranhos) que não se encontram, pois o espaço é um lugar de não interação, (BAUMANN, 2001, p. 114) mas o fato de se estar nesse (não lugar) chamado de lugar de consumo coletivo a exemplo dos shopping centers, é sentirse integrado, como parte do todo, como pertencente ao lugar, de fazer parte, de integrarse a ele.

Aponta Zygmunt Baumann que os não lugares "não requerem domínio da sofisticada e difícil arte da civilidade, uma vez que reduzem o comportamento em público a preceitos simples e fáceis de aprender" (BAUMANN, 2001,p. 119).

Por outro lado, para explorar as possibilidades emancipatórias, Boaventura de Souza Santos (2009, p. 347-348) ao destacar os três grandes topos: a fronteira, o barroco e o Sul, importa aqui, apenas a fronteira enquanto forma "privilegiada de sociabilidade",

\footnotetext{
${ }^{22}$ Comenta: "No encontro de estranhos não há uma retomada a partir do ponto em que o último encontro acabou, nem troca de informações sobre as tentativas, atribulações ou alegrias desse intervalo, nem lembranças compartilhadas: nada em que se apoiar ou que sirva de guia para o presente encontro. O encontro de estranhos é um evento sem passado. Frequentemente é também um evento sem futuro (o esperado é não tenha futuro), uma história para "não ser continuada' uma oportunidade única a ser consumada enquanto dure e no ato, sem adiamento e sem deixar questões inacabadas para outra ocasião". (BAUMANN, 2001. p.111-112).
} 
são características desse viver na fronteira "uso muito selectivo e instrumental das tradições trazidas para fronteira por pioneiros e emigrantes", assim como novas "formas de sociabilidade; hierarquias fracas, pluralidade de poderes e de ordens jurídicas; fluidez das relações sociais; promiscuidade entre estranhos e íntimos; misturas de heranças e invenções”. (SANTOS, 2009, p. 347-348).

Viver na fronteira, é sem dúvida "viver nas margens sem viver uma vida marginal", na fronteira, repita-se com Boaventura de Souza Santos, (2009, p. 350) todos são "migrantes indocumentados ou refugiados em busca de asilo". ${ }^{23}$ Isso não significa que na fronteira tudo seja "instável, transitório ou precário".

Mais especificamente, no que tange a migração, os migrantes, sujeitos esses "que vivem $a$ e $n a$ fronteira podem ser classificados em categorias como fronteiriços, aqueles nascidos nessa zona de fronteira; os fronteiriços nacionais migrantes, que são os provenientes de outras regiões do país; e os fronteiriços internacionais migrantes, que incluem todos os estrangeiros"(MARCANO, 1996). Além dos "viajantes", aqueles que fazem da fronteira "um lugar de trânsito, de cruzamento diário por motivos laborais, de diversão e lazer"(CLIFFORD, 1999). São novas situações que surgem de migração como herança do século XX e grande desafio do século XXI (PATARRA, Acesso 09 out 2012).

Por isso, é preciso ir além, além do campo geográfico, pois contemporâneamente a noção de fronteira "deve ser entendida enquanto territorialidade permeável à mobilidade social, em que as relações sociais constituem-se" (BUTTIERRES, 2011). Veja-se que a fronteira além do limite físico é considerada como área de interação. A noção contemporânea de território, deve necessariamente compreender além do limite físico, o conteúdo imaterial, cuja "sociedade e o território devem ser simultaneamente ator e objeto da ação". (SANTOS, 2000).

A territorialidade é um processo inclusivo, incorporando novos e velhos espaços de forma “oportunista e/ou seletiva, não separando quem está 'dentro' de quem está fora”.(M.I.N.2005, p. 17).

23 Enfatiza: "Na transição paradigmática, a subjectividade de fronteira navega por cabotagem,(forma de navegação dominante sec. XV) guiando-se ora pelo paradigma dominante, ora pelo paradigma emergente. E se é verdade que o seu objetivo último é aproximar-se tanto quanto possível do paradigma emergente, ela sabe que só ziguezagueando lá poderá chegar e que, mais do que uma vez, será o paradigma dominante a continuar a guia-la. Cabotando assim ao longo da transição paradigmática, a subjetividade de fronteira sabe que navega num vazio cujo significado é preenchido, pedaço a pedaço, pelos limites que ela vai vislumbrando, ora próximos, ora longínquos[...]." (p.354-355).”(SANTOS, 2009. p.350-355). 
A fronteira é um lugar tanto de trocas, como de comunicação, vez que, o limite jurídico do território "é uma abstração, gerada e sustentada pela ação institucional no sentido de controle efetivo do Estado territorial, portanto, um instrumento de separação entre unidades políticas soberanas”.(MACHADO, 2000, p. 9-10).

\section{3 ÁREA E ZONA DE FRONTEIRA - AS CIDADES GÊMEAS}

Noutra seara, no campo da geografia, as fronteiras são "molduras dos Estadosnações", (MARTIN, 1992, p. 46) associada à guerra, por vezes até num sentido negativo, ${ }^{24}$ ou ainda, ao aspecto do limite físico, geográfico, a zona de fronteira, que difere de faixa e área de fronteira.

O conceito de fronteira é diferente de acordo com a disciplina na qual passa a ser verificado, as fronteiras, no entanto, podem ser classificadas segundo Ernesto González Posse (Acesso 25 mai, 2013) em zonas de fronteira (de menor dimensão) e região (para maior alcance). De acordo com os objetivos, comenta que nas zonas de fronteira há uma maior preocupação em que serviços e infraestrutura sejam melhorados, ao contrário das regiões de fronteira que voltam a sua preocupação para o desenvolvimento (PUCCI, 2010).

A faixa de fronteira brasileira está contida na Lei $n^{\circ} 6.634$ de 1979 é a norma que identifica a faixa de fronteira como região estratégica ao Estado em harmonia com os ideais de justiça e desenvolvimento na referida região.

É nas zonas fronteiriças que se estabelecem a dimensão do espaço-lugar “onde os desafios e tensões entre a continuidade e o câmbio se estabelecem de modo mais agudo e ali o cotidiano é atravessado pelas relações com os países vizinhos”.(GRIMSON, 2002, p. 19). Assim ocorre também uma redefinição da função das zonas fronteiriças, conforme já referia Camilo Vallaux, (1914, p. 406). "Não é como linhas, mas como zonas, como convém considerar as fronteiras".

\footnotetext{
24 “O tema das "fronteiras" tem sido bastante polêmico ao longo da história, embora em certas ocasiões ele tenha permanecido relativamente esquecido. É bem provável que para a grande maioria das pessoas a simples menção à palavra "fronteira" provoque uma reação negativa, posto que, efetivamente, a memória humana registra um sem-número de conflitos e muitos sofrimentos em torno do seu estabelecimento, manutenção ou destruição. Assim, associamos quase mecanicamente a ideia de "fronteira" à de "guerra"." (MARTIN, 1992, p. 11).
} 
A análise das cidades na fronteira Internacional, faz-se necessária, como adverte Lia Osorio Machado, (2010, p. 4) cujos limites são importantes tanto para governos como para a população de uma maneira geral, é uma simbologia, um espaço relacional e não dicotômico, além de cosmopolita, a exemplo das cidades gêmeas.

Portanto, essas cidades - cosmopolitas ${ }^{25}$ - na fronteira Internacional, têm nos seus limites a separação e a diferença, ${ }^{26}$ o começo e o fim. Refere Lia Osorio Machado (2010, p. 74):

Embora operem em todo o território nacional, essas redes encontram um ambiente que favorece o estabelecimento de nódulos de articulação transnacionais nas cidades de fronteira, particularmente nas cidades situadas na divisa internacional - o ambiente fronteiriço. Não porque as regras são ambíguas, mas porque podem se beneficiar e negociar com as diferenças de normas entre estados vizinhos estabelecidas pelos limites internacionais.

No que se refere ao Estado-Nação, existe um conjunto de formas "institucionais de governo mantendo um monopólio administrativo sobre um território com fronteiras (limites) demarcado", (GIDDENS, 1981, p. 190) caracteriza-se geograficamente a faixa de fronteira, em razão da "faixa de até $150 \mathrm{~km}$ de largura ao longo de $15.719 \mathrm{~km}$ da fronteira terrestre brasileira, que abrange quinhentos e oitenta e oito municípios de onze estados”. (PREUS, 2011).

Os Estados com faixa de fronteira são: Acre, Amapá, Amazonas, Mato Grosso, Mato Grosso do Sul, Pará, Paraná, Rio Grande do Sul, Rondônia, Roraima e Santa Catarina. Essa área adverte Lislei Terezinha Preuss, (2011) “corresponde a 27\% do território brasileiro e reúne uma população estimada em dez milhões de habitantes, ou seja, $19 \%$ da população brasileira". Sendo que o Brasil faz fronteira "com dez países da

\footnotetext{
${ }^{25}$ Cosmopolitismo "as cidades-gêmeas são, no mínimo, bi-nacionais, mas com freqüência abrigam pessoas de diferentes lugares do país e do mundo, em parte atraídas pela possibilidade de ser mais um 'estrangeiro' em meio a outros. Geralmente considerado como algo 'natural' pelos habitantes locais, o ambiente cosmopolita fundamentado na diversidade cultural e étnica pode ser explorado por políticas de desenvolvimento urbano alimentos, música, bilingüismo, arquitetura, etc., são elementos que enriquecem a qualidade de vida e a convivência transfronteiriça ao mesmo tempo em que reafirmam a heterogeneidade do lugar e, com ela, a possibilidade de se articular a redes de diversos tipos e origens". (MACHADO, 2010. p.11).

${ }^{26} \mathrm{O}$ limite internacional "foi estabelecido como conceito jurídico associado ao Estado territorial no sentido de delimitar espaços mutuamente excludentes e definir o perímetro máximo de controle soberano exercido por um Estado central. Apesar de não ter vida própria nem existência material (por definição, a linha é abstrata e não pertence a nenhum dos lados) o limite internacional não é uma ficção e sim uma realidade geográfica que gera outras realidades". (MACHADO, 2010. p.59-60).
} 
América do Sul e busca a ocupação e a utilização dessa Faixa de forma compatível com sua importância territorial estratégica”. (PREUS, 2011).

Para tanto, a visualização ${ }^{27}$ no mapa abaixo se faz necessária, para compreensão do todo no qual se encontra inserido o objeto da análise da fronteira do Rio Grande do Sul com o Uruguai. Veja-se a tipologia básica das subregiões da faixa de fronteira brasileira, com os países vizinhos.

Figura 1 - Mapa da Faixa de Fronteira do Brasil

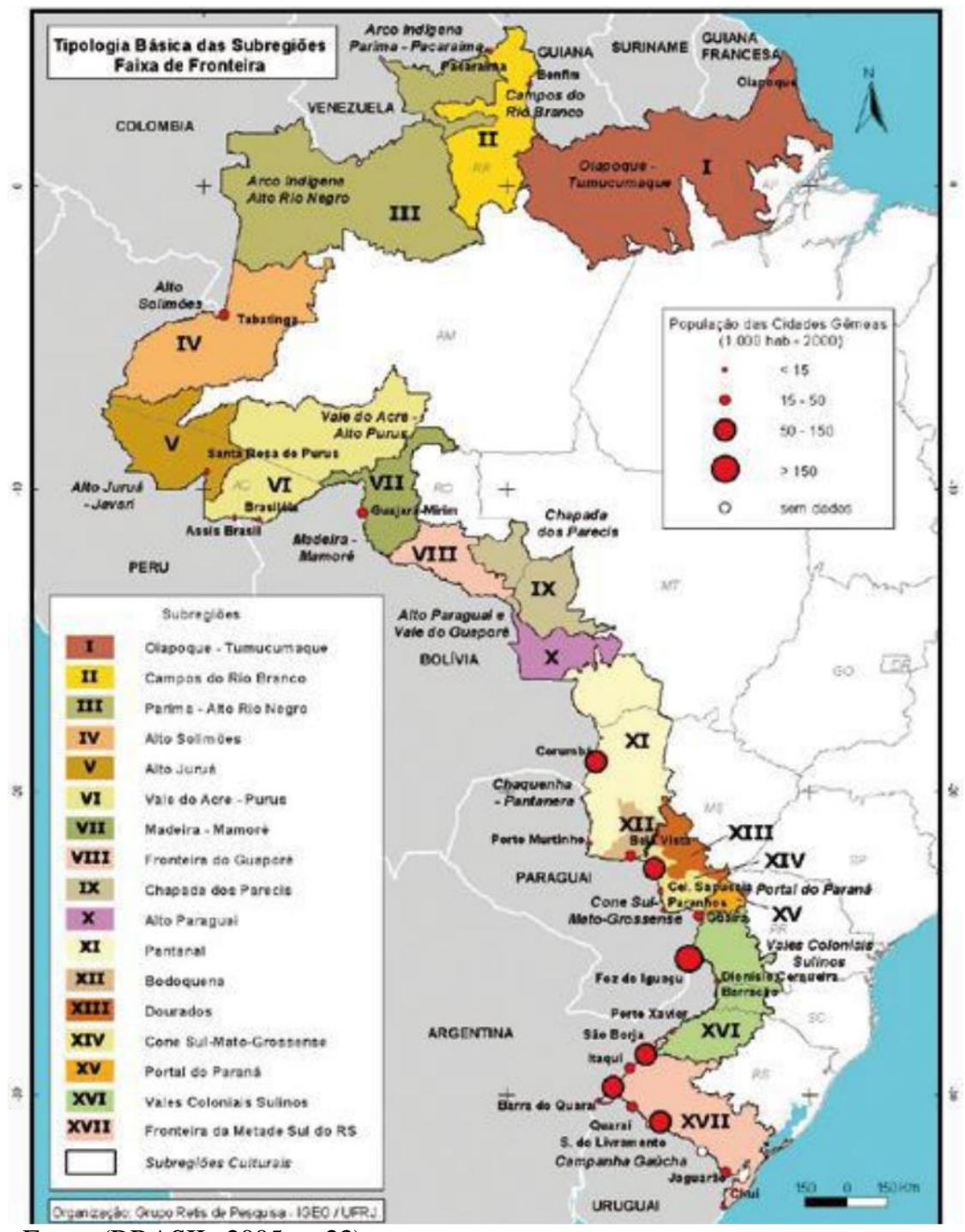

Fonte: (BRASIL, 2005, p. 23).

No que tange a evolução histórica legislativa desse conceito comenta Renata de Souza Furtado (2009, p. 30) do gabinete da Segurança Nacional do Brasil:

${ }^{27}$ Obs.: "utiliza-se deste valioso recurso visual, pois uma imagem ou mapa vale mil palavras" (HARVEY, 1999, p.23). 


\begin{abstract}
No Brasil, a faixa de fronteira variou de tamanho ao longo da história. Iniciouse com 10 léguas (66 quilômetros) na Lei do Império de 1891 e na Constituição de 1891. Na Constituição de 1934, passou para 100 quilômetros e, na Constituição de 1937, foi alterada para 150 quilômetros. E foi assim mantida até os dias atuais, com a diferença de que a regra normativa de dimensão de área saiu do nível constitucional e foi para a esfera infraconstitucional. Portanto, o tema faixa de fronteira foi constitucional até o ano de 1937. Houve um lapso temporal de 9 (nove) anos até a promulgação da Constituição de 1946, quando foi editada Lei específica para a faixa de fronteira de 150 quilômetros (Lei no 2.597/55). O tema manteve-se regrado por norma infraconstitucional durante a vigência da Constituição de 1967 e EC no 1/69. Com a Constituição de 1988 (CF/88), o tema voltou para a esfera constitucional, com a introdução de um conceito mais flexível de dimensão mediante a utilização da expressão "até 150 quilômetros".
\end{abstract}

Existem, contudo, diferentes fronteiras adverte ainda Renata de Souza Furtado, (2009, p. 83) por um lado, “as fronteiras geográficas (que podem ser artificiais ou naturais); as fronteiras econômicas; as zonas de desenvolvimento nas áreas de fronteiras; e as fronteiras de defesa". Por outro lado, há fronteiras conflituosas e também aquelas que não representam ameaça para a segurança interna dos países. Também existem as fronteiras geopolíticas.

O conceito de fronteira, que vem sendo radicalmente modificado como afirma, Arturo Villarreal (2009, p. 159), de estática em dinâmica:

\begin{abstract}
Passamos da idéia de uma fronteira estática, mais rígida, com sentido de pertencimento, para uma fronteira que requer, como já disse o General Felix, um grau de complementação, de cooperação e de convivência, o que facilita sobremaneira a integração dos países. No caso específico do Uruguai, a fronteira vai desde a Barra do Quaraí, com Bella Unión, até a Barra do Chuí. Isto significa que esta fronteira, delimitada inicialmente pelo Tratado de 1851, com uma extensão de 1.068 quilômetros, está perfeitamente demarcada. Os trabalhos, já concluídos, ficaram a cargo de uma Comissão Mista de Limites e Caracterização da Fronteira Brasil-Uruguai. Da extensão total, 608 quilômetros estão demarcados por rios e canais; 140 quilômetros, por lagoas; 57 quilômetros, por linhas convencionais; e mais 262, por divisor de águas. Os documentos que estabeleceram tais limites fronteiriços são o já mencionado Tratado de 1851; o Tratado da Lagoa Mirim, de 1909; a Convenção do Arroio São Miguel, de 1913; e o Estatuto Jurídico da Fronteira, de 1933.
\end{abstract}

Aponta também Arturo Villarreal (2009, p. 161) que muitos são os acordos e ajustes entre Brasil e Uruguai, principalmente na área da educação, moradia, trabalho e saúde 28

\footnotetext{
${ }^{28}$ Refere: "Esses acordos preveem o que chamamos de seminário taller, normalmente conduzido pelo Ministério de Desenvolvimento Social do Uruguai, por meio da Direção de Coordenação Territorial, que por sua vez já realizou cinco seminários nos quais foram discutidas as políticas de integração de fronteira, bem como a complexidade e a diversidade desse ambiente. Destes seminários participam pessoas do Ministério de Desenvolvimento Social e do Ministério das Relações Exteriores do Uruguai e do Brasil. Também estão integrados a esse trabalho os cônsules de fronteira ou de cidades fronteiriças de ambos os lados, e os prefeitos e
} 
Exemplificando, no âmbito da Comissão Binacional que assessora de Saúde na Fronteira, o Ajuste Complementar do Convênio de Segurança Social, "no que tange a primeira atenção médica nos centros de saúde que não pertençam ao seu lugar de origem”. Ou seja, nessa zona fronteiriça, os "cidadãos de ambos os países circulam livremente e, no caso, tanto os cidadãos uruguaios como os brasileiros podem ser atendidos, em primeira instância, nas instituições públicas da cidade em que se encontrem”. Só após "essa primeira atenção, serão encaminhados para o atendimento correspondente do seu país de origem".(VILLARREAL, 2009, p. 161-162).

Outro aspecto também merece ser destacado, pela importância, quanto ao Acordo sobre Permissão de Residência, Estudo e Trabalho, referente ao acesso à educação, ao trabalho, à segurança social e à atenção médica de 2002. E o Ajuste Complementar ao Acordo para Prestação de Serviços de Saúde em $2009,{ }^{29}$ e um último aspecto, diz respeito ao Comitê Binacional de Intendentes e Prefeitos de Fronteira, incluído no marco da nova Agenda de Cooperação e Desenvolvimento Fronteiriço Brasil-Uruguai. ${ }^{30}$

E mais recentemente, com o Decreto n. ${ }^{\circ} 8.455$, de 2015, o Acordo entre os dois governos para a Criação de Escolas e/ou Institutos Binacionais Fronteiriços Profissionais e/ou Técnicos e para o Credenciamento de Cursos Técnicos Binacionais

autoridades locais. O último seminário taller foi realizado na cidade de Chuí, fronteira com os dois países, de 22 a 25 de abril passado. O resultado dos trabalhos inclui o recolhimento das inquietações dos cidadãos fronteiriços, das autoridades e da sociedade civil, concernentes a problemas que afetam suas vidas cotidianas. Com o fim de avançar nessas problemáticas, dando um alcance de conteúdo aos ajustes complementares sobre segurança social, as autoridades consulares dos Estados contratantes (Brasil e Uruguai) poderão representar, sem mandato especial, os nacionais de seus países perante as autoridades competentes e as entidades gestora responsáveis pela manutenção da segurança social do outro Estado. Também poderão acordar com atores locais a execução dos postulados contidos nos acordos de cooperação em matéria ambiental; verificar, no âmbito da Comissão Binacional Assessora de Saúde na Fronteira, a aplicação efetiva do Ajuste Complementar do Convênio de Segurança Social [...] (VILLARREAL, 2009. p.161-162).

29 Aduz: "Tudo isso leva a elaborar um manual de uso exclusivo do cidadão fronteiriço, do qual constem seus direitos, derivados desses acordos, e também uma campanha de informação em nível local. Quer dizer, cada pessoa que mora ali, passa a estar ciente dos seus direitos. Nesse sentido, também estariam incluídos os direitos outorgados aos cidadãos fronteiriços pelo Acordo sobre Permissão de Residência, Estudo e Trabalho, referentes ao acesso à educação, ao trabalho, à segurança social e à atenção médica”. (VILLARREAL, 2009. p.162).

30 Aduz: "As autoridades, que se reúnem indistintamente em cidades fronteiriças do Uruguai ou do Brasil, chegaram a um acordo no qual são considerados os direitos dos cidadãos residentes fronteiriços e a necessidade de fazer chegar a esses cidadãos as informações retromencionadas. Estes acordos binacionais podem ser resumidos em quatro pontos: fomentar a implementação de medidas para solucionar situações referentes às normas vigentes; desenvolver e concretizar ações no sentido de alcançar o exercício pleno dos direitos dos cidadãos; fomentar espaços que contribuam à difusão das normas locais; e comprometer-se em constituir-se no elo entre a cidadania e as autoridades do Poder Executivo central da República Federativa do Brasil e do Uruguai. [...] Uruguai e Brasil estão inseridos no marco normativo do Mercosul. Esse marco, que evidentemente facilita a livre circulação, não só no aspecto comercial, como também cultural e outros, muitas vezes se contrapõe às legislações locais que, de acordo com o marco do Mercosul, devem ser modificadas para adaptar-se, pois o acordo do Mercosul teria força bastante para isso.”. (VILLARREAL, 2009. p.162). 
Fronteiriços.(Acesso em: 27 de julho de 2015). Sem dúvida, um grande avanço na área da educação, visto ser uma reivindicação de anos.

Pois bem, a análise se dá na fronteira da metade sul do Rio Grande do Sul, portanto, geograficamente a fronteira Brasil-Uruguai é a maior fronteira que o Rio Grande do Sul possui, são aproximados $1.003 \mathrm{~km}$, sendo a mais longa das fronteiras do Brasil. E onde $60 \%$ de sua extensão é definida por uma linha imaginária, sendo que "nessa região vivem aproximadamente 517 mil habitantes, que transitam livremente entre os dois países".(DIÁRIO POPULAR, 2009).

Desde 2005, têm-se várias propostas de reestruturação em âmbito nacional, e na Proposta de Reestruturação do Programa de Desenvolvimento da Faixa de Fronteira, do Ministério da Integração Nacional, (2005, p. 23) verifica-se que:

em muitos lugares, é a interação entre as atividades econômicas locais,
tradições, crenças e costumes que gera e consolida na população local
sentimentos de pertencimento e auto-estima, essenciais ao fortalecimento do
senso de auto-organização, à emergência da inovação e do incentivo a trocas e
colaboração com o "não-próprio".

Já no Plano de Trabalho Interfederativo para a Integração Fronteiriça de 2010, (Acesso, 19 jul. 2015), refere que "o meio geográfico que melhor caracteriza a zona de fronteira é aquele formado pelas cidades-gêmeas", pelo grande potencial que apresenta para uma efetiva integração.

Noutro enfoque, a relação binacional entre Brasil e Uruguai, foi estruturalmente condicionada por uma economia de fronteira, e, assim, definida pela constante vulnerabilidade criada por variações cíclicas na política de taxa de câmbio e moedas, assim se criou uma "interação entre o legal e o ilegal, que é à base do tecido social da fronteira". 31

Uma particularidade da região de fronteira Brasil-Uruguai é que desde o fim do século XX, é que essa região fronteiriça foi o ambiente onde "proliferaram as manifestações das oposições sul-rio-grandense e uruguaia”.(RANGEL, acesso 19. Jul. 2012).

Por isso que a segurança nacional é um ponto tão importante a ser considerado, pois, historicamente, a região da fronteira foi palco de inúmeras disputas “militares-

\footnotetext{
31 Tradução livre de: "La modalidad de ese relacionamiento bi-nacional ha sido estructuralmente condicionada por una economía fronteriza, y por tanto definida por la constante vulnerabilidad generada por las variaciones cíclicas de la política cambiaria de las monedas de Uruguay y Brasil. Así se ha constituido un acervo patrimonial fuertemente caracterizado por el juego entre lo legal y lo ilegal el que es la base del entramado social fronterizo". (MAZZEI, 2000).
} 
territoriais, de modo que a concepção hegemônica dominante por longo período foi de uma área limite, em que a demarcação territorial fazia-se necessária para a segurança nacional”.(BUTIERRES, 2011).

Outro ponto é o "efeito pêndulo" na vida econômica da fronteira Brasil-Uruguai, com oscilações da moeda de cada país. E cuja estabilidade superior de um em relação ao outro, influencia na vida de seus habitantes. ${ }^{32}$

Vale mencionar que a fronteira brasileira e a fronteira uruguaia tinham seus "pontos de soldagem sob a forma dessas cidades geminadas que são bicéfalas no nível administrativo, mas perfeitamente complementares no nível econômico". (SOUZA, 1996, p. 83). É o que se pode chamar de interferência da fronteira, ou seja, a capacidade das cidades criarem um "campo de força que resulta da complementaridade econômica através da geração de uma economia básica flutuante, segundo as condições de câmbio. Portanto, são cidades que se complementam além do território nacional”. (NEVES, 1971).

Levando em consideração as características físicas dos municípios, o Ministério da Integração Nacional, (Acesso, 19 jul. 2015) identificou cinco tipos de interação transfronteiriça, pois as "simetrias e assimetrias entre cidades-gêmeas nem sempre decorrem de diferenças no nível de desenvolvimento dos países e sim de sua própria dinâmica e da função que exercem para os respectivos países": 1) Margem; 2) Zonatampão; 3) Frentes; 4) Capilar e 5) Sinapse. ${ }^{33}$

\footnotetext{
32 Tradução livre de: "En esas fronteras sus moradores históricos, el común de las personas, tejen la trama de historia que les ha correspondido en función de sus condiciones de vida. Poseen nuevas o antiguas ocupaciones, aspiran tal vez solamente a un trabajo temporario, saben lo que es vivir a pesos uruguayos dada la fortaleza del real, viven transformaciones vertiginosas (free-shops, etc.) “. (DE MARTINO; ORTEGA; LEMA, 2008, p.239).

${ }^{33}$ Verifique-se: A Margem se caracteriza por um tipo de interação em que a população fronteiriça de cada lado do limite internacional mantém pouco contato entre si, exceto de tipo familiar ou para modestas trocas comerciais. As relações são mais fortes com a estrutura nacional de cada país do que entre si. A ausência de infraestrutura conectando os principais núcleos de povoamento é uma característica do modelo. O segundo tipo, Zona-tampão aplica-se às zonas estratégicas onde o Estado central restringe ou interdita o acesso à faixa e à zona de fronteira, criando parques naturais nacionais, áreas protegidas ou áreas de reserva, como é o caso das terras indígenas. O terceiro tipo é caracterizado pelas frentes de povoamento. No caso das interações fronteiriças, a "Frente" também designa outros tipos de dinâmicas espaciais, como a frente cultural (afinidades seletivas), a frente indígena ou a frente militar. As interações do tipo Capilar podem ocorrer somente no nível local, como no caso das feiras, exemplo concreto de interação e integração fronteiriça espontânea. Pode ocorrer por meio de trocas difusas entre vizinhos com limitadas redes de comunicação, ou resultam de zonas de integração espontânea, nas quais o Estado intervém pouco, principalmente não investindo na construção de infraestrutura de articulação transfronteiriça. $\mathrm{O}$ modelo Sinapse refere-se à presença de alto grau de troca entre as populações fronteiriças apoiado pelos Estados contíguos. As cidades-gêmeas mais dinâmicas podem ser caracterizadas de acordo com esse modelo. (Ministério da Integração Nacional, Acesso, 19 jul. 2015).
} 
Ou seja, o modelo Sinapse justamente por referir-se ao alto grau de troca entre as populações fronteiriças apoiadas pelos Estados contíguos, merece a atenção aqui para o estudo, pois as cidades-gêmeas Santana do Livramento (BR) e Rivera (UR) assim como, o Chuí (BR) e Chuy (UR), representam muito bem essa possibilidade de trocas, em razão da fronteira ser composta por uma rua, (fronteira seca) e não por um rio-ponte, como a maioria delas.

O Ministério da Integração (Acesso em: 27 jul. 2015) define conceito de cidades gêmeas, por meio de portaria, ou seja, que se caracterizam pela integração urbana com países vizinhos, e lista os 29 municípios brasileiros que se enquadram nesta condição:

Segundo o Ministério da Integração Nacional, serão considerados cidades gêmeas os municípios cortados pela linha de fronteira, seja essa seca ou fluvial, integrada ou não por obra de infraestrutura, que apresentem grande potencial de integração econômica e cultural, podendo ou não apresentar a unificação da malha urbana com cidade do país vizinho. Não serão consideradas cidades gêmeas aquelas com população inferior a 2 mil habitantes. A necessidade de se definir as cidades gêmeas ocorre porque há crescente demanda desses municípios por políticas públicas específicas por serem fronteiriços e importantes para a integração sul-americana. Em geral, a divisão é feita por uma rua, ficando o Brasil de um lado e o país vizinho do outro. São exemplos desse tipo de cidade Tabatinga (AM), e Leticia, na Colômbia. Ou ainda Santa do Livramento (RS) e Rivera, no Uruguai.

Especificamente na divisa entre Brasil e Uruguai estão localizados ao todo, seis pares de cidades-gêmeas, são elas: Chuí-Chuy, Jaguarão-Rio Branco, Aceguá-Acegua, Santana do Livramento-Rivera, Quaraí-Artigas e Barra do Quaraí-Bella Unión.

Vale a pena mencionar, segundo dados do IBGE de 2010, que a fronteira com os demais países do MERCOSUL é integrada por sessenta e nove municípios e uma população de 1.438.206 habitantes. Já o Rio Grande do Sul é o Estado com maior número de municípios na fronteira. (PREUS, 2011). ${ }^{34}$

\footnotetext{
34 “O Rio Grande do Sul é o Estado que possui maior número de municípios na fronteira (42,6\%), totalizando vinte e nove municípios, sendo dez na fronteira com Uruguai e dezenove na fronteira com a Argentina. Em segundo lugar, está o Estado do Paraná com dezoito municípios (26,5\%) sendo nove na fronteira com a Argentina e nove na fronteira com o Paraguai. O Estado de Mato Grosso do Sul possui onze municípios (16,2\%) na fronteira com o Paraguai e o Estado de Santa Catarina dez municípios $(14,7 \%)$ na fronteira com a Argentina. Na fronteira com a Argentina estão localizados trinte e oito municípios brasileiros (55,9\%), na fronteira com o Paraguai vinte municípios $(29,4 \%)$ e na fronteira com o Uruguai dez municípios $(14,7 \%)$. Em termos populacionais há certa correspondência, pois o RS agrega 45,4\% da população total dos municípios da linha de fronteira do Brasil com o MERCOSUL, seguido do Estado do Paraná com 32,1\%, do Estado de Mato Grosso do Sul com 17,7\% e do Estado de Santa Catarina com apenas 4,9\% da população total. Com referência aos países, há uma inversão quando à fronteira brasileira com o Paraguai. Esta assume o primeiro lugar no contingente populacional, correspondendo a 42,7\%. A Argentina está em segundo lugar com 33,8\% e o Uruguai com 23,6\%." (PREUSS, 2011).
} 
A denominação 'cidades-gêmeas' como - no caso da fronteira internacional brasileira - compõem arranjos espaciais bastante diversificados. Dificilmente apresentam tamanhos urbanos similares, "inclusive em alguns casos um dos núcleos na divisa não chega a ser uma 'cidade', não estão necessariamente em fronteiras secas ou formam uma conurbação; podem não ocupar posições simétricas em relação à divisa”. (MACHADO, 2010, p. 66).

Veja-se no mapa abaixo a identificação das cidades gêmeas do país:

Figura 2 - Mapa das cidades-gêmeas e suas divisas

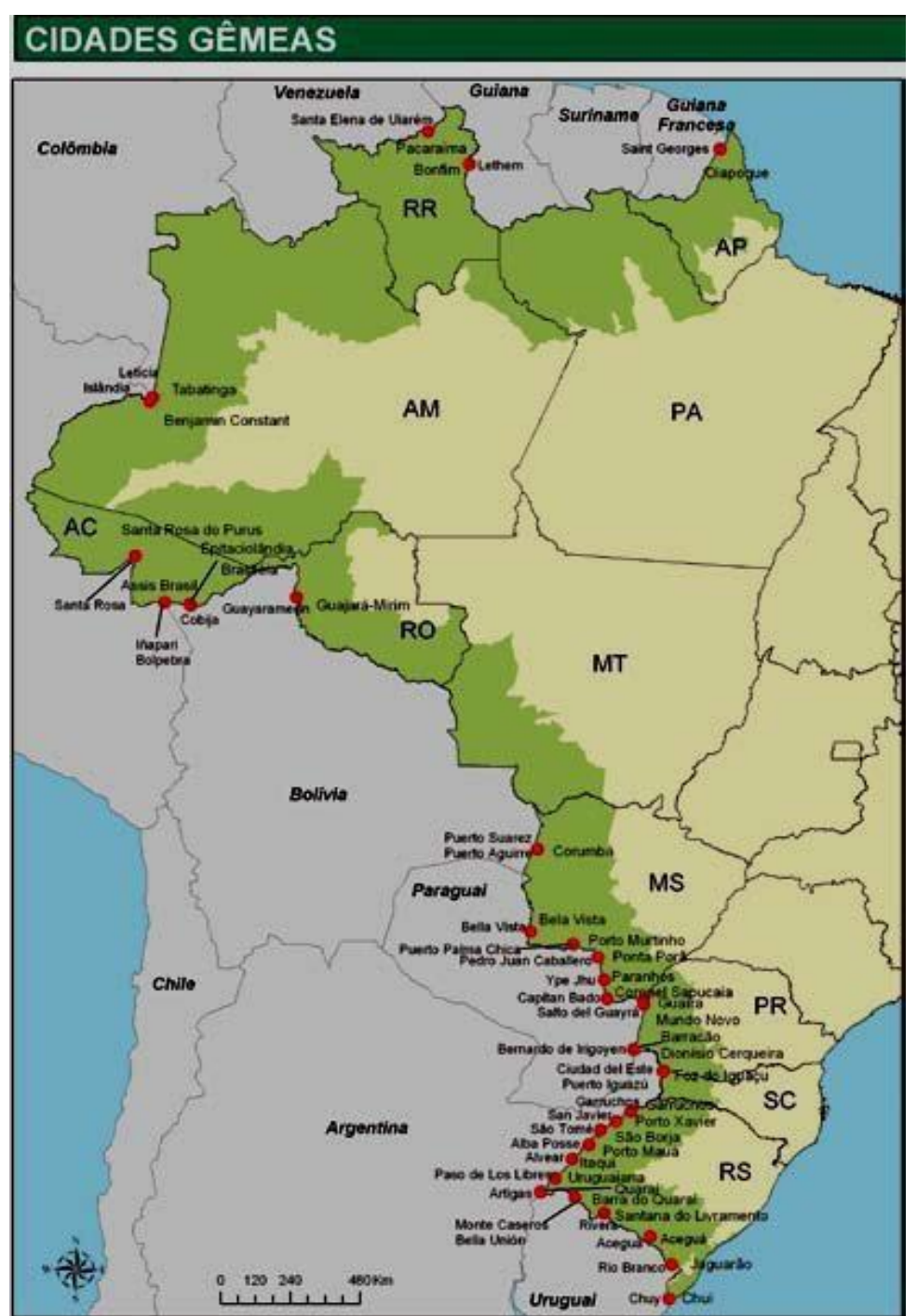

Fonte: (MI/SPR/PDFF 2005, Acesso 19. Jul. 2012).

As cidades-gêmeas na fronteira Brasil-Uruguai são marcadas por intensos fluxos migratórios, são aglomerações urbanas, aos pares ao longo de todo limite internacional, geralmente possuem como característica marcante os intensos fluxos de trocas e têm funcionado como importantes 'nós' entre os mercados dos países vizinhos. (FERREIRA, Acesso 13 out. 2010). 
Sabe-se que o fluxo migratório inclui, entre outros, a busca por serviços de saúde, trabalho, moradia, pois o fluxo constante, quer dizer a (i)migração/deslocamento das pessoas exige pelo menos um melhor planejamento, e que necessariamente deve levar em conta as particularidades desses locais. (MACHADO, STEIN, BASTOS, Acesso 21 de. 2010).

É uma fronteira singular, única, cuja vida cotidiana nas cidades gêmeas, exemplificando: Rivera (Uruguay) y Sant'Ana do Livramento (Brasil) afirma Gladys Bentancor, (2010, p. 73) é incomparável, muito embora seja comum associar-se a noção de fronteira ao conflito, guerra, vigilância, repressão ou controle ao mesmo tempo o desejo de liberdade. ${ }^{35}$ E propõe uma mudança conceitual observando a diferença entre limite e fronteira, e cuja área de fronteira, compreende a fronteira internacional, construída por meio de disputas e conflitos, e que são parte da "memória coletiva" de um povo. ${ }^{36}$

As fronteiras estão carregadas de simbologias, de ambiguidades, "pois ao mesmo tempo em que impedem, permitem a ultrapassagem”, (MELO, 1997, p. 68-69).

Percebe-se, contudo, que a linha imaginária da fronteira, não une e nem separa efetivamente, é um ponto de partida e de chegada, tornou-se símbolo de dois países ao mesmo tempo.

Algumas das observações de Karla Maria Muller, (Acesso 15 jul. 2015) na pesquisa realizada em Santana do Livramento e Rivera, no que diz respeito às relações entre os vizinhos, e essa barreira invisível, podem ser apontadas aqui:

\begin{abstract}
A fronteira existente em Livramento-Rivera é tratada - com orgulho - por seus habitantes como "A Fronteira da Paz": "aqui há integração do Uruguai com o Brasil, acontecem episódios onde a boa intenção exerce um domínio, somos uma só cidade, pois sozinhas [Livramento e Rivera] não podem viver; ao invés
\end{abstract}

\footnotetext{
35 Tradução livre de: "El común de la gente, asocia casi mecánicamente la noción de frontera a la de conflicto, guerra, vigilancia, represión o control, por lo que la relaciona al cercenamiento de libertades. Pero en contraposición, es también el deseo de libertad expresado por grupos autonomistas, que crea nuevos territorios y por ende nuevas fronteras. Las áreas fronterizas consideradas confines territoriales, ante el reordenamiento regional que impone la implantación de procesos de integración de estados nacionales, como el MERCOSUR, pasan a ocupar centralidades, que pueden no pasar del simple dato geográfico. Los nuevos escenarios mundiales, apertura de mercados y la consiguiente globalización han provocado un aumento de las desigualdades sociales y regionales, que se intensifican en los países menos desarrollados y con economías más débiles”. (BENTANCOR, 2010. p.74).

36 Tradução livre de: "Límite y Frontera: Partiendo de consideraciones de concepción lineal o espacial proponemos un cambio conceptual significativo, para el estudio de las áreas fronterizas. Es común entender que los términos límite y frontera son sinónimos, sin embargo son dos conceptos diferenciados etimológicamente y cargados de significados conceptuales, de los cuales surgen interrelaciones, pero donde también surge que la riqueza conceptual atribuible al término frontera es mucho más amplia que la de limite”. (BENTANCOR, 2010).
} 
de um enfrentamento entre o Brasil e o Uruguai, há um entrosamento há muito tempo, até porque os primeiros moradores de Rivera eram portugueses e brasileiros". [...] As diferenças entre brasileiros e uruguaios são destacadas com respeito pelos fronteiriços e são poucos os relatos onde tais diferenças são vistas com negatividade. Os temas de conflitos são trabalhados, na sua grande maioria, com vistas a buscar uma aproximação. Ao serem questionados sobre a existência da divisa, confirmam e apontam onde se dá o contato: a rua, o parque, os pequenos marcos construídos em concreto e colocados espaçadamente de modo a formar uma linha demarcatória. Não vão muito além destas marcas físicas e salientam que "aqui a fronteira é ligada, mas ao mesmo tempo é separada; as duas são uma só, a barreira é invisível”.

Ainda, quanto às particularidades, a fronteira Brasil-Uruguai, possui essas muitas similitudes, bem próprias como a do significado de "ser gaúcho". 37 A tradição gaúcha refere noutra via, Ruben Oliver, (2006, p. 160-161) diz respeito também a comportamentos, cujos CTG's ${ }^{38}$ são um grande e bom exemplo, e aqui se volta às fronteiras culturais e simbólicas. ${ }^{39}$

Para Pablo José Ciccolella (1997, p. 64) quando refere uma redefinição de fronteiras, territórios e mercados, enquanto marco do capitalismo de blocos, adverte que os processos de integração têm grande potencialidade, uma capacidade de transformação e reorganização tanto econômica quanto socioterritorial, em nível nacional, supranacional ou continental, ao mesmo tempo em que representa também além da integração, uma segregação, fragmentação e exclusão. ${ }^{40}$

\footnotetext{
${ }^{37}$ A "vida de fronteira" é elemento de identidade; pertencimento de seus habitantes, os quais quando indagados sobre onde vivem muitos respondem "eu sou da fronteira". Em relação à fronteira Brasil-Uruguai, esse sentimento de identificação é incrementado pela identidade cultural advinda de processos sócio-históricos, pois tanto de um lado quanto de outro os habitantes são identificados como "gaúchos". (BUTIERRES, 2011).

38 "A adoção da tradição originária da região da Campanha por habitantes de outras áreas do Rio Grande do Sul significou um primeiro processo de desterritorialização da cultura gaúcha que saiu de sua origem e adquiriu novos significados em novos contextos. Hoje há CTGs em todas as regiões do Rio Grande do Sul. [...] E onde há gaúchos há CTGs. Hoje, 37\% dos CTGs estão no Rio Grande do Sul. A manutenção da cultura gaúcha por parte dos rio-grandenses que migraram para outros estados representa um novo processo de desterritorialização que é importante porque a cultura gaúcha continua com seus descendentes que muitas vezes nunca estiveram no Rio Grande do Sul. [...] Estima-se que atualmente haja aproximadamente um milhão de brasileiros vivendo nos Estados Unidos, Europa e Japão. E onde há gaúchos há CTGs. Assim, em 1992, foi criado um CTG em Los Angeles que acabou servindo de estímulo para a criação de outros. No mesmo ano, foi criado um CTG em Osaka, Japão. Este último tem o sugestivo nome de CTG Sol Nascente, numa prova de que as culturas viajam com seus portadores e se aclimatam em outros solos". (OLIVEN, 2006, 160-161).

39 "Se antigamente as culturas tendiam a ser associadas a um território e a identidades definidas, o que se verifica atualmente é um cruzamento das fronteiras culturais e simbólicas que faz com que haja uma desterritorialização dos fenômenos culturais. Uma manifestação simbólica que surge num contexto migra para outros e é recontextualizada. É claro que essa adoção não é passiva e implica sempre reelaboração. Isso significa que as culturas se tornam cada vez mais híbridas". (OLIVEN, 2006, p.166).

${ }^{40}$ Tradução livre de: "Los procesos de integración poseen uma gran potencialidad y capacidad de transformación y reorganización económica y socioterritorial, tanto a escala nacional como supranacional o continental. Sin embargo, resulta previsible que no todos las áreas o territorios supuestamente involucrados em la integración de economías nacionales, participarán con protagonismo semejante em el proceso integrador. Algo similar sucederá sectorialmente y socialmente. De modo que integración, también supone fragmentación, segregación y exclusión de territorios, economías regionales, sectores productivos y sectores sociales, así como el desmantelamiento de ciertos rubros de la prodición y de la infraestructura en algunas regiones". (CICCOLELLA, 1997, p.64-65).
} 
No mesmo sentido de linha divisória, invisível, marco que separa, e que une, em area de fronteira, como a de Santana do Livramento e Rivera, também exemplificativamente o marco divisório na cidade gêmea, do Estado do Rio Grande do Sul, portanto co-irmã - Chui no Brasil e Chuy no Uruguai - também separadas por uma rua, mais especificamente uma avenida, que curiosamente do lado brasileiro a avenida se chama "avenida Uruguai” e do lado uruguaio, a avenida se chama "avenida Brasil”.

Por outro lado, adverte Elsa Laurelli, (1997, p. 175) no que chamou de novo mapa para o Cone Sul da América Latina, que algumas regiões sairiam lucrando e outra restariam excluídas, ${ }^{41}$ pois as experiências Mercosul e NAFTA ignoram algumas situações para aumentar a competitividade territorial. Atualmente, regiões e circuitos produtivos não rentáveis, são abandonados a própria sorte. Assim como nas regiões mais avançadas, as disparidades continuam, surgindo "novos pobres e marginalizados".(CICONELLA, 1997, p. 64-65). ${ }^{42}$

Assim como nas duas (2) exemplificações acima, o mesmo se dá com as cidades gemeas que fazem fronteira do Brasil, como um todo (vide mapa) cujas dimensões são quilométricas, portanto os desafios são enormes, assim como os aspectos concernentes à lingua, cultura, identidade, da localização geografica, dos conflitos históricos, etc.

\section{CONSIDERAÇÕES FINAIS}

O Século XX se consagrou como o século da mobilidade humana são (i)migrantes/deslocados/refugiados, e não será diferente, pelo menos no primeiro quartel do século XXI, pois em todas as suas acepções, continua-se a visualizar o século dessa mobilidade, em busca da concretização de direitos sociais, não apenas de emprego, (mas do pleno emprego); da moradia, (mas sim, moradia digna); saúde, (e sim saúde integral); educação (não apenas básica, mas em nível superior); acolhimento e solidariedade, (no próprio país, ou outro país); proteção, (principalmente jurídica, política, etc.); e

\footnotetext{
${ }^{41}$ Tradução livre de: "El nuevo mapa para el Cono Sur de América Latín": "De los procesos citados resultarían regiones que obtienen beneficios y regiones que serán excluidas. Em las primeras resultarán beneficiados los sectores más poderosos, los grandes capitales monopólicos y los sectores medios integrados; em las segundas, los efectos negativos se difundirán em todos sectores sociales”. (LAURELLI, 1997, p.175.)

${ }^{42}$ Tradução livre de: [...] Desgraciadamente, las experiencias de integración tales como el NAFTA o Mercosur, tienden no sólo a ignorar esta situación, sino a potenciar la competitividad interterritorial. Actualmente, las 'regiones no rentables', así como los circuitos productivos no rentables y los ciudadanos no rentables son abandonados a su sorte. Por supuesto aún em las regiones más avanzadas del mundo continúan habiendo disparidades internas, diferenciais socioeconómicas, pobres y marginados. Y no sólo esto, sino que además están apareciendo 'nuevos pobres' y 'nuevos marginalizados'.” (CICCOLELLA, 1997, p.64-65).
} 
principalmente de dignidade, (com amplo e efetivo cumprimento de normas/tratados/acordos ou ajustes nacionais e internacionais, com o respeito aos direitos humanos e fundamentais). O que se deseja, é uma dinâmica de proteção efetiva, voltada ao ser humano, enquanto sujeito de direitos e deveres, enquanto ser social, enquanto pessoa.

$\mathrm{Na}$ percepção tradicional a fronteira é o limite, o corte, a descontinuidade, a barreira entre Estados Nacionais. Na perspectiva da integração fronteiriça surge um novo espaço conjunto, ganha uma redefinição, de espaço-lugar, de sentimento de pertença, um lugar que possa chamar e reconhecer como seu, que lhe seja próprio, a fim de que possa estabelecer relação de identidade, firmando vínculos coletivos e afetivos. A identidade do lugar se une, se funde e se converge em um lugar próprio daqueles que passam a ocupar o lugar, e aqui é perfeitamente possível trazer a fronteira enquanto não-lugar ou lugar incomum.

Na seara da Integração entre Brasil e Uruguai, foi realizado importante "Acordo para Permissão de Residência, Estudo e Trabalho a Nacionais Fronteiriços Brasileiros e Uruguaios" em 2002, além de um "Ajuste Complementar ao Acordo para Permissão de Residência, Estudo e Trabalho a Nacionais Fronteiriços Brasileiros e Uruguaios, para Prestação de Serviços de Saúde", firmado em 2008, que representou um avanço, visto que os fronteiriços podem utilizar dos serviços de saúde de ambos os lados, tanto do Sistema Único de Saúde do Brasil - (SUS) e Sistema Nacional Integrado de Saúde (SNIS), embora em termos práticos tenha alguns impecilhos, pois não significou a liberação do acesso total/integral dos fronteiriços ao sistema de saúde da outra parte, e nem que haja cobertura total nos atendimentos por parte do SUS/SNIS.

E recentemente, o Acordo para a Criação de Escolas e/ou Institutos Binacionais Fronteiriços Profissionais e/ou Técnicos e para o Credenciamento de Cursos Técnicos Binacionais Fronteiriços, o que representou um avanço maior ainda, visto ser uma reivindicação de anos dos fronteiriços dos dois países, capaz de além de contemplar a área da educação, efetivar o direito social a educação.

Por fim, na redefinição da fronteira, a inclusão de - iguais e desiguais - que vivem nesse lugar incomum, atípico, não lugar, num espírito fraterno, pacífico, solidário, e que dispõe dos Acordos/Ajustes, para efetivar alguns direitos sociais como educação, trabalho, moradia, saúde. 


\section{REFERÊNCIAS}

AUGÉ, Marc. Los «no lugares» espacios del anonimato: Una antropología de la Sobremodernidad (Título del original en francés: Non-lieux. Introduction á une anthropologie de la surmodenité. Edition de Seuil, 1992. Colection La Librairie du XX é siecle, sous la direction de Maurice Olender). Traducción: Margarita Mizraji, Quinta reimpresión, Barcelona: Editorial Gedisa, S.A., 2000. p.56.

AUGÉ, Marc. Não-lugares: introdução a uma antropologia da supermodernidade. Campinas: Papirus, 1994. (Coleção Travessia do Século). p.141.

BALLER, Leandro. Cultura, identidade e fronteira: Transitoriedade Brasil/Paraguai (1980-2005). Dissertação de Mestrado. Programa de Pós-Graduação em História da Faculdade de Ciências Humanas da Universidade Federal da Grande Dourados, 2008.

BAUMANN, Zygmunt. Modernidade Líquida. Tradução: Plínio Dentzien. Rio de Janeiro: Jorge Zahar Editor, 2001..

BENTANCOR, Gladys. Una fronteira singular. La vida cotidiana en ciudades gemelas: Rivera (Uruguay) y Sant' Ana do Livramento (Brasil). In: Dilemas e diálogos platinos. Orgs: Angel Nuñes, Maria Medianeira Padoin, Tito Carlos Machado de Oliveira. Dourados, MS: Ed.UFGD, 2010.

BRASIL. Ministério da Integração Nacional. Proposta de Reestruturação do Programa de Desenvolvimento da Faixa de Fronteira. Brasília: Ministério da Integração Nacional, 2005.

BRASIL. Ministério da Integração Nacional. Agencia Brasil. Disponível em: http://agenciabrasil.ebc.com.br/geral/noticia/2014-03/portaria-do-ministerio-daintegracao-define-conceito-de-cidades-gemeas. Acesso 27 jul. 2015.

BORGES FILHO, Ozíris. A questão da fronteira na construção do espaço da obra literária. Revista do Centro Ítalo-Luso-Brasileiro de Estudos Lingüísticos e Culturais. Triceversa. Assis, v.2, n.1, maio-out.2008.

BOURDIEU, Pierre. O poder simbólico. Trad. Fernando Tomaz. 8. ed. Rio de Janeiro: Bertrand Brasil, 2005.

BÜHRING, Marcia Andrea. Direitos humanos e fundamentais, migração nas fronteiras Brasil e Uruguai: uma análise dos déficits do direito social à saúde da mulher nas cidades gêmeas: Santana do Livramento-BR/Rivera-UR e Chuí-BR/Chuy-UR. Tese de Doutorado. PUCRS, Porto Alegre, 2013.

BURKE, Peter. O que é história cultural? Rio de Janeiro: Jorge Zahar Editor, 2005.

BUTIERRES, Maria Cecília. Assimetrias no acesso e na garantia do Direito à Saúde do Trabalhador na fronteira Brasil-Uruguai. Dissertação de Mestrado PUCRS. Orientadora Jussara Maria Rosa Mendes. Porto Alegre, 2011. 
CAMPIGOTO, José Adilçon. Fronteira e História Cultural. In: SCHALLENBERGER, Erneldo. (org.). Cultura e memória social: territórios em construção. Cascavel: Coluna do Saber, 2006, p. 11-32.

CASTELLO, Iara Regina. Áreas de fronteira: territórios de integração, espaços culturalmente identificados. In: HAUSEN, Ênio Costa, LEHNENE, Arno Carlos (orgs.) Prática de integração nas fronteiras: temas para o Mercosul. Porto Alegre: EdUFRGS: Instituto Goethe/ICBA, 1995.

CASTELLS, Manuel. "El espacio de los flujos". Cap 6. In: La era de la Información, Economía, Sociedad y Cultura. La sociedad red. (Siglo veintiuno editores) Buenos Aires: Alianza Editorial, Vol. 1 y 3, 2006.

CERTEAU, Michel de. A invenção do cotidiano: 1 . Artes de fazer. Rio de Janeiro: Vozes, 2003.

CICCOLELLA, Pablo Jose. Redefinición de fronteras, territorios y mercados em el marco del capitalismo de bloques. In: CASTELLO, Iara Regina; KOCH, Mirian Regina; OLIVEIRA, Naia; SCHÄEFFER, Neiva Otero e STROHAECKER, Tânia. (orgs.). Fronteiras na América Latina: espaços em transformação. Porto Alegre: Ed. Universidade. UFRGS. Fundação de Economia e Estatística, 1997. (Fundação de Economia e Estatística).

CLIFFORD, James. Itinerários transculturales. Barcelona: Gedisa, 1999.

DE MARTINO, Mónica; ORTEGA, Elizabeth; LEMA, Silvia. Tendencias Actuales en el Patrón de Protección Social Claro-Oscuros en la Era Progresista. In: MERCOSUL em Múltiplas Perspectivas. Org. MENDES, Jussara et.al. Porto Alegre: EDIPUCRS, 2008.

DUPLA Atenção à Saúde. Diário Popular, Pelotas. p.12, 10 dez. 2009.

ELIAS, Norbert; SCOTSON, John L. Os estabelecidos e os outsiders: sociologia das relações de poder a partir de uma pequena comunidade. Rio de Janeiro: Jorge Zahar, 2000.

FERREIRA, André Cassino. Interações na Fronteira Brasil Uruguai: um Estudo de Caso das Cidades de Jaguarão e Rio Branco. 2008. Disponível em: <http://www.igeo.ufrj.br/fronteiras>. Acesso em: 13 out. 2010.

FERREIRA, Aurélio Buarque de Holanda. Novo dicionário da língua portuguesa. 2.ed. Rio de Janeiro: Nova Fronteira, 1986.

FOUCAULT, Michael. Microfísica do poder. Rio de Janeiro: Edições Graal, 1985.

Fronteiras dos Pensamento. Conferencistas. Disponível em: <http://www.fronteirasdo pensamento.com.br/portal/conferencista/66/>. Acesso em: 01 fev. 2013.

FURTADO, Renata de Souza. Seminário Fronteiras e Segurança Nacional: América do Sul, México e Estados Unidos. Brasília: Presidência da República, Gabinete de Segurança Institucional,

2009. 
GIDDENS, Anthony. A Contemporary Critique of Historical Materialism. London: Macmillan, 1981, vol. I.

GRIMSON, Alejandro. El otro lado del río: periodistas, nación y Mercosur en la frontera. 1 ed. Buenos Aires: Universitária de Buenos Aires: Eudeba, 2002.

HALL, Stuart. Da diáspora: identidades e mediações culturais. Belo Horizonte: EdUFMG, 2003.

HANCIAU, Núbia J. Entre-Lugar. In: FIGUEIREDO, Eurídice (Org.). Conceitos de literatura e cultura. Juiz de Fora: UFJF, 2005.

HARVEY, David. Condição Pós-moderna. São Paulo: Ed. Loyola, 1999.

HISSA, Cássio E. V. A mobilidade das fronteiras: inserções da Geografia na crise da modernidade. Belo Horizonte: Ed. da UFMG, 2006.

HOBSBAWM, Eric. Nações e nacionalismo desde 1780: programa, mito e realidade. Rio de Janeiro: Paz e Terra, 1994.

IICA. Plano de Trabalho Interfederativo para a Integração Fronteiriça. Disponível em $<$ http://www.iica.int/Esp/regiones/sur/brasil/Lists/DocumentosTecnicosAbertos/Attachment s/18/Afr\%C3\%A2nio\%20Jos\%C3\%A9\%20Ribeiro\%20de\%20Castro\%20-

\%20109383\%20-\%20Des\%20Regional\%20P6.pdf. Acesso em: 19 jul. 2015.

LAURELLI , Elsa. "Reestructuración económica en América Latina: Integración o Fractura de los Territorios Fronterizos". In: CASTELLO, Iara Regina; KOCH, Mirian Regina; OLIVEIRA, Naia; SCHÄEFFER, Neiva Otero e STROHAECKER, Tânia. (orgs.). Fronteiras na América Latina: espaços em transformação. Porto Alegre: Ed. Universidade. UFRGS. Fundação de Economia e Estatística, 1997. (Fundação de Economia e Estatística).

MACHADO, Lia Osório. Cidades na Fronteira Internacional: Conceitos e Tipologia. In: Dilemas e Diálogos Platinos. Fronteiras. Editora Gráfica Universitaria. PREC-UFPel. Editora UFGD. 2010.

Limites e Fronteiras: Da alta diplomacia aos circuitos da ilegalidade. In: Revista Território, ano V, no . 8. p.7-23. Universidade Federal do Rio de Janeiro. Rio de Janeiro, 2000 .

. Limites, fronteiras, redes. In: STROHAECKER, Tânia et al. (Org.). Fronteiras e espaço global. Porto Alegre: Associação dos Geógrafos Brasileiros - secção Porto Alegre, 1998.

MACHADO, Rosane Cardoso; STEIN, Airton Tetelbom; BASTOS, Gisele Alcina Nader. O paradoxo da saúde em cidades-gêmeas no sul do Brasil e no Uruguai. Disponível em: <http://www.fazendogenero.ufsc.br/9/resources/anais/1274972824_ARQUIVO_artigo.faze ndogenero.pdf>. Acesso em: $21 \mathrm{dez} .2010$. 
MALERBA, Jurandir. "Para uma teoria simbólica: conexões entre Elias e Bourdieu". In: CARDOSO, Ciro Flamarion; MALERBA, Jurandir (orgs.). Representações: contribuição a um debate transdisciplinar. Campinas: Papirus, 2000.

MARCANO, E. E. J. La construccion de espacios sociales transfronterizos entre Santa Elena de Uairén(Venezuela) y Villa Pacaraima (Brasil). Brasilia, 1996. Tese de Doutorado em Sociologia. Facultad Latinoamericana de Ciencias Sociales, Flacso. Universidade de Brasília.1996.

MARTIN, André Roberto. Fronteiras e nações. São Paulo: Contexto, 1992.

MARTINS, José de Souza. O tempo da fronteira: retorno à controvérsia sobre o tempo histórico da frente de expansão e da frente pioneira. In: MARTINS, José de Souza. Fronteira: a degradação do outro nos confins do humano. São Paulo: Hucitec, 1997.

MAZZEI, Enrique. Rivera (Uruguay)-Sant Ana(Brasil). Identidad, território e integración fronteriza. Montevideo: Rosgal, 2000.

MELO, José Luis Bica de. Reflexões conceituais sobre fronteira. In: CASTELLO, Iara Regina; KOCH, Mirian Regina; OLIVEIRA, Naia; SCHÄEFFER, Neiva otero e STROHAECKER, Tânia. (orgs.). Fronteiras na América Latina: espaços em transformação. Porto Alegre: Ed. Universidade. UFRGS. Fundação de Economia e Estatística, 1997.

MULLER, Karla Maria. TESE. Mídia e fronteira: jornais locais em Uruguaiana-Libres e Livramento-Rivera. Disponível em: <http://www.midiaefronteira.com.br/tese/cap4.htm\#4.2>. Acesso em: 15 jul. 2015.

NEVES, Gervásio Rodrigo. Rede Urbana da Zona de Interferência da Fronteira. In: Desenvolvimento Urbano do Rio Grande do Sul. Semanas Sociais do Rio Grande do Sul. V Semana. Porto Alegre: Editora A Nação, 1971.

OLIVEN, Ruben G. Territórios, fronteiras e identidades. In: SCHULER, Fernando; BARCELlOS, Marília de A. (Orgs.). Fronteiras: arte e pensamento na época do multiculturalismo. Porto Alegre: Sulina, 2006.

OSORIO, Helen. et alli (Orgs). "Espaço Platino: Fronteira Colonial no século XVIII" In: Praticas de Integração nas Fronteiras: temas para o Mercosul. Porto Alegre: EdUFRGS, Instituto Goethe/ICBA, 1995.

PADRÓS, Enrique Serra. Fronteiras e integração fronteiriça: elementos para uma abordagem conceitual. Revista do Instituto de Filosofia e Ciências Humanas, Porto Alegre, v. 17, n. 1/2, janeiro/dezembro, 1997. p.63-85.

PATARRA, Neide Lopes; BAENINGER, R. Migrações internacionais recentes: o caso do Brasil. In: PATARRA, Neide Lopes (Coord.) Emigração e imigração internacional no Brasil Contemporâneo. São Paulo: Fundo de Populações das Nações Unidas, 1996.

PEREIRA, Jacira Helena do Valle. Processos identitários da segunda geração de migrantes de diferentes etnias na fronteira Brasil-Paraguai. In: MARIN, Jérri R;VASCONCELOS, 
Cláudio A de (orgs.) História Região e identidades. Campo Grande: Editora da UFMS, 2003.

POSSE, Ernesto González. Marco conceptual de la integración fronteriza promovida: las iniciativas de integración fronteriza. Disponível em: $<$ http://www.iadb.org/intal/intalcdi/integracion_latinoamericana/_documentos/156Revista_Completa.pdf $>$. Acesso em: 25 mai. 2013.

PREUSS, Lislei Teresinha. O pacto pela saúde nas cidades-gêmeas da fronteira do rio grande do sul com a Argentina e o Uruguai. Porto Alegre, 2011. Tese (Doutorado em Serviço Social). Faculdade de Serviço Social, PUCRS. 2011.

PUCCI, Adriano Silva. O Estatuto da Fronteira Brasil-Uruguai. Brasília: Ed. Funag, 2010.

RAFFESTIN, Claude. Por uma geografía do poder. São Paulo: Ática, 1993.

. A ordem e a desordem ou os paradoxos da fronteira. In: OLIVEIRA, Tito C. M. de (Orgs.). Território sem limites: estudos sobre fronteiras. Campo Grande: Ed. da UFMS, 2005 .

RANGEL. Carlos Roberto da Rosa. Fronteira Brasil-Uruguai: entre o nacional e o regional (1928/1938). Territórios e Fronteiras - Revista do Programa de Pós-Graduação em História da Universidade Federal de Mato Grosso, v. 6, n. 2, jul./dez. 2005 - Cuiabá-MT. Disponível em <http://www.ppghis.com/revista_artigo/arquivos/v6-n2-jul-dez-2005-miolo.pdf>. Acesso em: 19 jul. 2012.

REALE, Miguel. O direito como experiência: introdução a epistemologia jurídica. 2. ed. São Paulo: Saraiva, 1992.

SANTOS, Boaventura de Sousa. A crítica da razão indolente: contra o desperdício da experiência. Para um novo senso comum. A ciência, o direito e a política na transição paradigmática. 7. ed. São Paulo: Cortez, 2009. Vol. 1.

Pela mão de Alice: o social e o político na pós-modernidade. São Paulo: Cortez, 1997.

SANTOS, Milton. O Espaço do Cidadão. 5. ed. São Paulo: Studio Nobel, 2000.

O retorno do território. In: SANTOS Milton et al. Território: globalização e fragmentação. 2. ed. São Paulo: Hucitec, 1996.

SOUZA, Susana B. de. Os caminhos e os homens do contrabando. In: CASTELLO, Iara Regina (Org.) Práticas de Integração nas fronteiras: temas para o Mercosul. Porto Alegre: Editora da Universidade/ UFRGS, 1996.

VALLAUX, Camilo. Geografia social. El suelo y el Estado. Madrid: Daniel Jorro Editor, 1914.

VILLARREAL, Arturo. Seminário Fronteiras e Segurança Nacional: América do Sul, México e Estados Unidos. Brasília: Presidência da República, Gabinete de Segurança Institucional, 2009. 